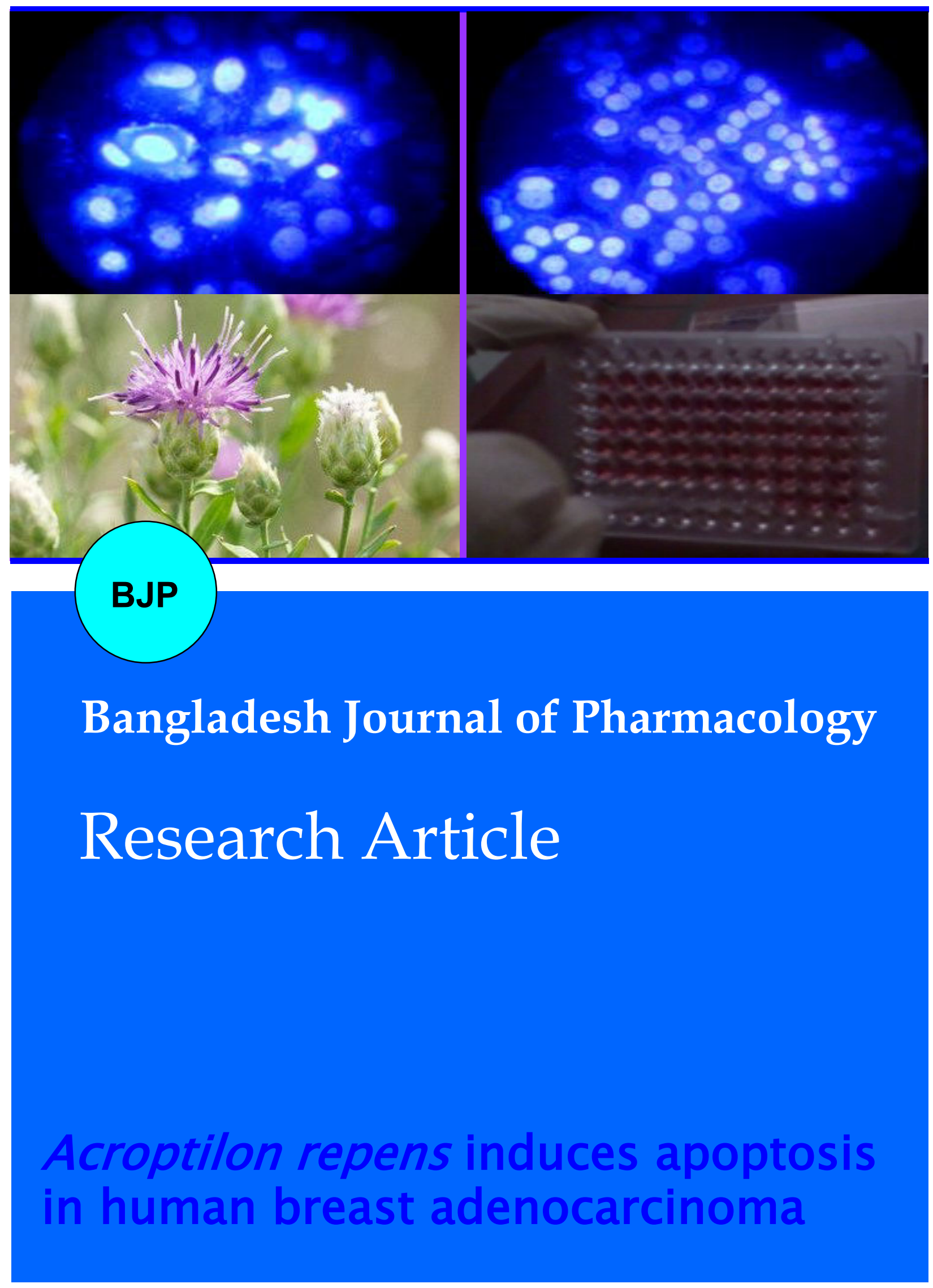


Abstracted/indexed in Academic Search Complete, Agroforestry Abstracts, Asia Journals Online, Bangladesh Journals Online, Biological Abstracts, BIOSIS Previews, CAB Abstracts, Current Abstracts, Directory of Open Access Journals, EMBASE/Excerpta Medica, Global Health, Google Scholar, HINARI (WHO), International Pharmaceutical Abstracts, Open J-gate, Science Citation Index Expanded, SCOPUS and Social Sciences Citation Index

\title{
Acroptilon repens induces apoptosis in human breast adenocarcinoma
}

\author{
Mahmoud Mosaddegh', Mahboobeh Irani' ${ }^{2}$ and Maryam Hamzeloo-Moghadam1 \\ ${ }^{1}$ Traditional Medicine and Materia Medica Research Center, Shahid Beheshti University of Medical Sciences and \\ Department of Traditional Pharmacy, School of Traditional Medicine, Shahid Beheshti University of Medical \\ Sciences, Tehran 1516745811, Iran; ${ }^{2}$ Traditional Medicine and Materia Medica Research Center, Shahid Beheshti \\ University of Medical Sciences, Tehran 1516745811, Iran.
}

\begin{tabular}{|c|}
\hline Article Info \\
\hline 25 August 2018 \\
\hline 22 November 2018 \\
\hline Available Online: 14 December 2018 \\
\hline DOI: $10.3329 /$ bjp.v13i4.38026 \\
\hline $\begin{array}{l}\text { Cite this article: } \\
\text { Mosaddegh M, Irani M, Hamzeloo- } \\
\text { Moghadam M. Acroptilon repens in- } \\
\text { duces apoptosis in human breast } \\
\text { adenocarcinoma. Bangladesh J Phar- } \\
\text { macol. 2018; 13: 362-66. }\end{array}$ \\
\hline
\end{tabular}

\section{Introduction}

Natural products have been the focus of cancer researches for many years. They can be beneficial to human health and prevent cancer and suppress tumor growth through cell death pathways including apoptosis in cancer cells (Fulda, 2010). Formerly, providing medicines from natural sources was time-consuming. However, findings of the present modern techniques have speed up (Safarzadeh et al., 2014). In recent years, many plant extracts or their isolated components have been assessed for apoptotic potential and different mechanism of actions have been proposed for their toxicity towards cancer cells.

Acroptilon repens (L.) DC. is the only species of Acroptilon growing in Iran (Mozaffarian, 1999). The plant belongs to Asteraceae family (formerly known as Compositae). There is not much report about the biological activities of this species. Meanwhile, Asteraceae family is famous for comprising species with cytotoxic and apoptotic components. Thus, in the present study, A. repens was evaluated for cytotoxicity and probable apoptotic potential considering that there has been no reports about such activities previously.

\section{Materials and Methods}

\section{Plant material}

Golestan Province is located in the North of Iran, from where A. repens was collected. The plant was authenticated by a botanist from the Traditional Medicine and Materia Medica Research Center, Shahid Beheshti University of Medical Scientec, Tehran, Iran. A voucher specimen was kept for future reference (TMRC-1668). The plant was shade dried and ground. Ten gram of powder was macerated with methanol at room temperature. Twenty four hours later, the mixture was filtered and the residue was exposed to fresh solvent. The process continued for three days when the filtrates were combined, concentrated under pressure and dried. The dried extract was kept in a refrigerator until the time of the experiments. 


\section{Cell culture and cytotoxicity assay}

Two human breast adenocarcinoma, MCF-7 and MDAMB-468, were collected from the Pasture Institute, Tehran, Iran. The MTT assay was used to evaluate the cytotoxicity of the extract. In MTT assay, the ability of the live cells is attributed to the conversion of the yellow MTT to purple formazan salt (HamzelooMoghadam et al., 2013; Naghibi et al., 2014). The cells were exposed to the methanol extract $(9,000$ and 8,000 cells/well in 96-well plates for MCF-7 and MDA-MB468 cells, respectively). Forty eight hours passing the exposure, the extract was removed and the cells received MTT solution $(0.5 \mathrm{mg} / \mathrm{mL})$ for another 4 hours. At the end of the experiment, DMSO was used to dissolve the formed formazan crystals and the absorbance was recorded at $570 \mathrm{~nm}$. The $\mathrm{IC}_{50}$ was calculated afterwards (Hamzeloo-Moghadam et al., 2014).

\section{Hoechst 33258 staining}

The human breast adenocarcinoma cells were seeded in 96-well plates and exposed to the plant extract similar to the method as explained for MTT assay. They were, then, fixed with paraformaldehyde $4 \%$ for $30 \mathrm{~min}$ at

\section{Box 1: Cell Cycle Analysis by Flow Cytometer}

\section{Principle}

The amount of DNA stained dye incorporated is proportional to the amount of DNA which is measured in the flow cytometer. The emitted fluorescent signal yields an electronic pulse with a height (amplitude) proportional to the total fluorescence emission from the cell.

\section{Requirements}

Human breast adenocarcinoma cells; Centrifuge machine; Ethanol; Flow cytometer (FACSCalibur, BD Biosciences, USA); Incubator; Phosphate buffer solution; A. repens methanol extract; Propidium iodide; Ribonuclease A; Triton X-100; 6well plate; Eppendorf micropipette with microtips

\section{Procedure}

Step 1: Human breast adenocarcinoma cells $\left(4 \times 10^{5}\right.$ cells) were seeded in each well of 6 -well plate and incubated at $37^{\circ} \mathrm{C}$ for 24 hours

Step 2: The cells were then treated with A. repens methanol extract $(50-400 \mu \mathrm{M})$ for 24 hours

Step 3: Cells were collected and centrifuged

Step 4: Cells were resuspended in cold phosphate buffer solution

Step 5: The solution was centrifuged again and received $1 \mathrm{~mL}$ ethanol for $30 \mathrm{~min}$ on ice

Step 6: Cells were, then, centrifuged $\left(18-24^{\circ} \mathrm{C}\right)$ and washed with cold phosphate buffer solution

Step 7: A solution containing propidium iodide $(20 \mathrm{mg} / \mathrm{mL})$, Triton X-100 $(0.1 \%)$, ribonuclease A $(10 \mu \mathrm{g} / \mathrm{mL})$ was added to room temperature. Finally, the fixative solution was removed and phosphate buffer solution was used for washing the cells and Hoechst $33258(1 \mu \mathrm{g} / \mathrm{mL})$ was added to the wells. The plates were kept in darkness (15 $\min , 37^{\circ} \mathrm{C}$ ), followed by repeating the washing step. The morphological characteristics were evaluated with a florescent microscope (Mosaddegh et al., 2018).

\section{Annexin V/Propidium iodide assay}

The MCF-7 and MDA-MB-468 cells received the extract for 24, 48 and 72 hours and 3, 24 and 48 hours, respectively. Afterwards, the cells were collected and assessed for apoptosis induction using Invitrogen FITC annexin $\mathrm{V} /$ dead cell apoptosis kit following the instructions. Five microliters of annexin- $V$ solution was added to the cells for $15 \mathrm{~min}$ in darkness, then propidium iodide was added and the cells were incubated for another $15 \mathrm{~min}$. The cell suspension was moved to flow cytometry tubes and analyzed by flow cytometer. Live, early apoptotic, late apoptotic and the cells undergoing necrosis were analyzed (Fallahian et al., 2015).

\section{Statistical analysis}

The $\mathrm{IC}_{50}$ value was determined using Microsoft Excel program. The experiments were repeated three times.

the cells for $30 \mathrm{~min}$ in dark at room temperature

Step 8: The suspension was then analyzed by flow cytometer

\section{Analysis of Results}

1. Measure the forward scatter and side scatter to identify single cells

2. Pulse processing is used to exclude cell doublets from the analysis

3. Propidium iodide has a maximum emission of $605 \mathrm{~nm}$ so can be measured with a suitable bandpass filter

\section{Precautions}

1. The number of cells to analyze used are critical (below 1,000 cells per sec) to get a good signal

2. Ethanol (70\%) should not be made with phosphate buffer solution as this causes protein precipitation on fixation.

3. Gently aspirate several times with a Pasteur pipet to obtain a mono-dispersed cell suspension, with minimal cell aggregation

4. RNA would interfere in the staining, the solution should contain ribonuclease $\mathrm{A}$

5. Exclude cell debris and aggregates. These will interfere with the measurement

6. Use gloves while preparing and using propidium iodide (a mutagenic).

7. Prepare fresh staining solution just before use.

\section{References}

Wang et al., 2016 


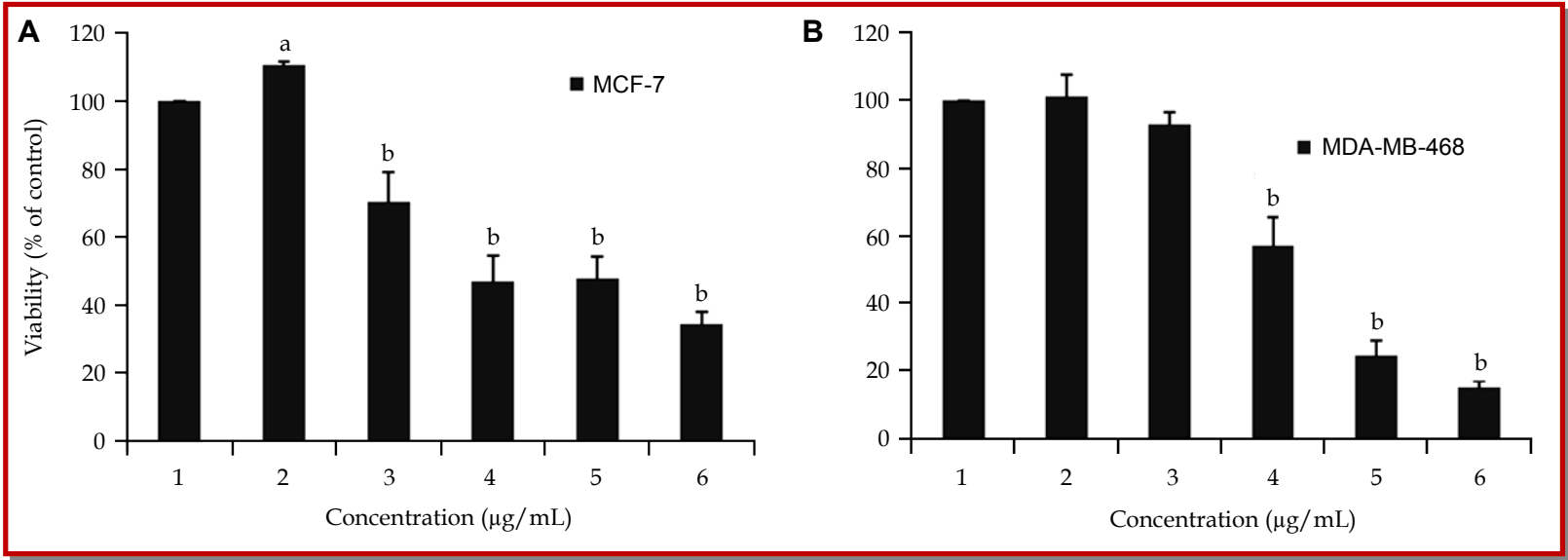

Figure 1: Cytotoxicity of the Acroptilon repens methanol extract in MCF-7 (A) and MDA-MB-468 (B) using MTT assay
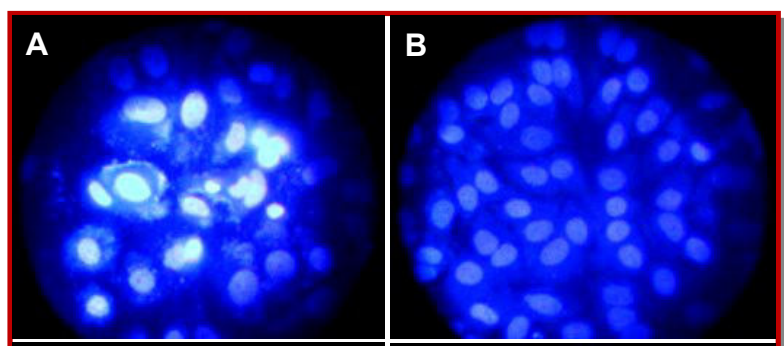

c

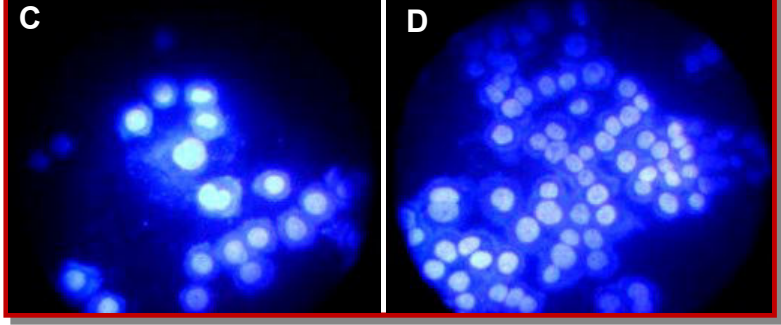

Figure 2: Hoechst 33258 staining in MCF-7 and MDA-MB468 cell lines. The cells were treated with $12 \mu \mathrm{g} / \mathrm{mL} \mathrm{A.re-}$ pens extract in MCF-7 (A), $50 \mu \mathrm{g} / \mathrm{mL}$ A. repens extract in MDA-MB-468 cells (C), DMSO 1\% as control in MCF-7 (B) and in MDA-MB-468 (D)

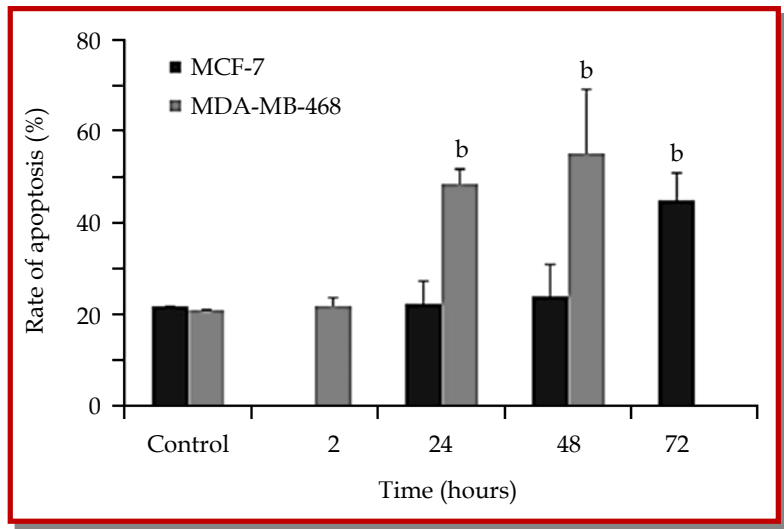

Figure 3: Rate of apoptosis in MCF-7 cells after 24, 48 and 72 hours treatment with $100 \mu \mathrm{g} / \mathrm{mL}$ A. repens extract and in MDA-MB- 468 cells after 3, 24 and 48 treatment with $35 \mu \mathrm{g} / \mathrm{mL}$ A. croptilon repens extract
For data comparison, one-way analysis of variance (ANOVA) followed by Dunnett's post hoc test was used. In all the cases, $\mathrm{p}<0.05$ was considered significantly different.

\section{Results}

Figure 1 and Figure 2 represent the results of the MTT and Hoechst assays. The $\mathrm{IC}_{50}$ values for the extract in MCF-7 and MDA-MB-468 cells were found to be 69.9 and $32.6 \mu \mathrm{g} / \mathrm{mL}$, respectively; while the values for 5 -FU in these cell lines were 0.91 and $1.27 \mu \mathrm{g} / \mathrm{mL}$, respectively. Chromatin condensation which makes the apoptotic cells look brighter under the fluorescence microscope in Hoechst 33258 assay could be observed.

In Figure 3, the control cells were negative for both annexin V-FITC and propidium iodide. The cells at the beginning stages of apoptosis were annexin V-FITCpositive, propidium iodide-negative cells while annexin V-FITC-positive, propidium iodide-positive cells were considered to be late apoptotic and propidium iodidepositive cells were considered as necrotic.

The cell phases appoint to the different periods in a cell cycle comprising growth and development in all living organisms. Every eukaryotic cell has four phases within the cell cycle, G1, S, G2 and M (Zhao et al., 2014). Different phases in a cell cycle after exposure to various concentrations of the plant extract have been shown in Figure 4 .

\section{Discussion}

A. repens extract induced apoptotic cell death in both MCF-7 and MDA-MB-468 cells and the rate of apoptosis (sum of early and late apoptotic cells) increased with increasing the time of exposure to the extract. On the other hand, nuclear morphological changes observed in the Hoechst 33258 staining could be an indication of apoptosis which was confirmed with the brilliant 


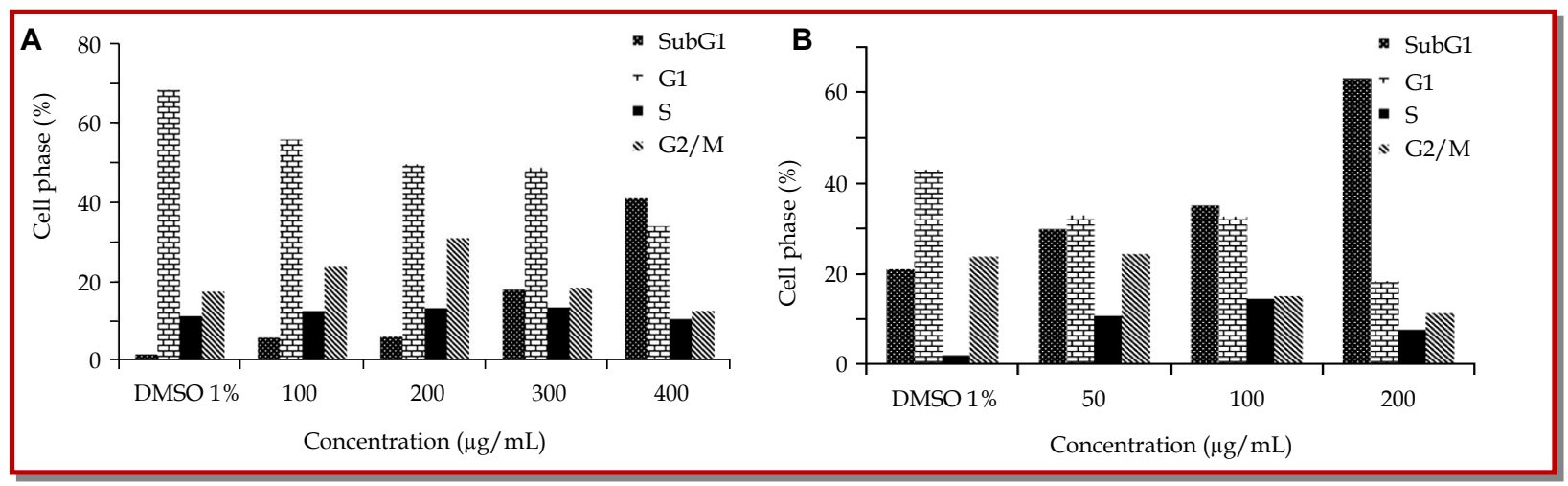

Figure 4: Effect of Acroptilon repens extract on cell cycle distribution of MCF-7 cells (A) and MDA-MB-468 cells (B)

condensations of chromatin in apoptotic cells of both breast adenocarcinoma cells; also, 24 hours exposure of the two breast cell lines to $A$. repens extract showed cell cycle arrest at SubG1 phase in a concentrationdependent manner which is an indication of apoptosis.

There are few reports about the constituents and biological activity of $A$. repens; however, a research on the ethanol and aqueous extract of $A$. repens, has presented the ethanol extract to be more potent and a considerable antioxidant and anti-cancer agent (Tursun at al., 2010). A number of previous studies dealt with the toxicity and apoptosis inducing properties of other plants from the same family (Asteraceae) in human breast cancer cell lines, which have been attributed to the sesquiteropene lacotones that are characteristics in this family or the flavonoids which are actually phenolic compounds. In a research by Galavi et al., apoptosis was induced in MCF-7 and MDA-Mb-468 cell lines by the hydro alcoholic extract of Achillea wilhelmsii. The $\mathrm{ED}_{50}$ in the cytotoxicity evaluation was found to be $25 \mu \mathrm{g} / \mathrm{mL}$ for the extract in both cell lines which is lower compared to the results of the present study. They could confirm apoptosis in the cell lines by annexin V method (Galavi et al., 2016). Antiproliferative and apoptotic potential of the ethyl acetate extract of Chamaemelum nobile in MCF-7 cells has been reported in another study. $\mathrm{IC}_{50}$ of $\mathrm{C}$. nobile in MCF-7 cells was calculated after $24,4 \mathrm{~h}$ and $72 \mathrm{~h}$ exposure of the cells to the ethyl acetate fraction of the plant in MTT assay. The results showed that 72 hours exposure presented the lowest $\mathrm{IC}_{50}$ value of $2 \mu \mathrm{g} / \mathrm{mL}$ compared to $90 \mu \mathrm{g} / \mathrm{mL}$ after 24 and 4 hours exposure; so the apoptosis studies were carried out regarding the $72 \mathrm{~h}$ concentration to show apoptosis induction confirmed by annexin V/PI assay demonstrating the cytotoxic activity to be due to late apoptosis and necrotic properties of the ethyl acetate fraction of the plant. Moreover, an increase in G2 phase was observed which suggested G2/M arrest in the cell cycle (Mostafapour et al., 2016) despite the subG1 arrest reported in the present study. Apoptosis was detected by the chloroform fraction of Eclipta alba, another member of Asteraceae family, in MCF-7 and MDA-MB-231 cells. The research was focused on different molecular pathways compared to our study but they could show that apoptosis was induced in the above breast cancer cell lines through the intrinsic pathway (Arya et al., 2015). Regarding Triple-negative breast cancer cells (TNBC), the extract of Taraxacum mongolicum has been found to be effective to induce cell apoptosis. The $\mathrm{IC}_{50}$ of the extract in MDA-MB-231 cells line which is also a breast cancer cell line was found to be 131.0, 101.6 and $80.7 \mu \mathrm{g} / \mathrm{mL}$ after 24,48 and 72 hours exposure in MTT assay, respectively and cell cycle arrest was reported in G2/M phase ( $\mathrm{Li}$ et al., 2017). 5FU, tamoxifen, toremifene, paclitaxel, docetaxel and many other anti-cancer agents have been investigated in cell line models and their mechanism of apoptosis induction has been studied. As examples, 5-FU which has been used in chemotherapy of different types of cancer (Pardini et al., 2011) has been also approved to treat breast cancer (National Cancer Institute, 2018). It has caused cell cycle arrest in G1/S phase that has been attributed to overexpression of p53 target genes involved in cell cycle and apoptosis (Hernández-Vargas et al., 2006). Tamoxifen which is another anti-cancer chemotherapeutic medication used in breast cancer (National Cancer Institute, 2018), is able to induce chromatin condensation and DNA cleavage (typical of apoptosis) in MCF-7 cells (Perry et al., 1995). Tamoxifen has been shown to inhibit cancerous inhibitor of protein phosphatase 2A (CIP2A) and phospho-Akt (p-Akt) which leads to apoptosis in MDA-MB-468 cells (Lui et al., 2014).

Considering the cytotoxicity and apoptosis studies in other plants of Asteraceae family, some have induced cytotoxicity in lower and some in higher concentrations compared to our study, some studies showed necrosis and late apoptosis while we reported early and late apoptosis. The phase for cell cycle arrest may also seem different, but all of these disagreements could be explained by the fact that different plants would possess different components with various potency and distinct mechanisms of action. Signs of apoptosis could appear whenever apoptosis is present but the nature of this phenomenon is very complex. In all of the experiments of the present work, apoptosis took place 
in lower concentrations in MDA-MB-468 cells compared to MCF-7 cells which show more sensitivity of these cells to the extract. Overall, our findings confirmed the cytotoxicity and apoptotic potential of A. repens extract; however isolation of the active components and studying the molecular details of apoptosis induction is necessary.

\section{Conclusion}

Regarding the results of the cytotoxicity and apoptosis studies of the present work, $A$. repens is introduced as a species with potential anticancer constituents which can be further considered for breast cancer studies.

\section{Acknowledgements}

The authors wish to thank Dr. Hamid Moazzeni Zahan for his assistance in collection and scientific identification of the plant. This research was financially supported by the Traditional Medicine and Materia Medica Research Center, Shahid Beheshti University of Medical Sciences, Tehran, Iran (Grant No. 169).

\section{References}

Arya RK, Singh A, Yadav NK, Cheruvu SH, Hossain Z, Meena S, Maheshwari S, Singh AK, Shahab U, Sharma C, Singh K, Narender T, Mitra K, Arya KR, Singh RK, Gayen JR, Datta D. Anti-breast tumor activity of Eclipta extract in-vitro and in -vivo: Novel evidence of endoplasmic reticulum specific localization of Hsp60 during apoptosis. Sci Rep. 2015; 5: 18457.

Fallahian F, Aghaei M, Abdolmohammadi MH, HamzelooMoghadam M. Molecular mechanism of apoptosis induction by gaillardin, a sesquiterpene lactone, in breast cancer cell lines: Gaillardin-induced apoptosis in breast cancer cell lines. Cell Biol Toxicol. 2015; 31: 295-305.

Fulda S. Modulation of apoptosis by natural products for cancer therapy. Planta Med. 2010; 76: 1075-79.

Galavi HR, Saravani R, Shahraki A, Ashtiani M. Antiproliferative and apoptosis inducing potential of hydro-alcoholic Achillea wilhelmsii C. Koch extract on human breast adenocarcinoma cell lines MCF-7 and MDA-Mb-468. Pakistan J Pharm Sci. 2016; 29(Suppl): 2397-403.

Hamzeloo-Moghadam M, Firouzi J, Saeidnia S, Hajimehdipoor H, Jamili Sh, Rustaiyan A. Gohari A. A cytotoxic hydroperoxy sterol from the brown alga, Nizamuddinia zanardinii. DARU J Pharm Sci. 2013; 21: 24.

Hernández-Vargas H, Ballestar E, Carmona-Saez P, von Kobbe C, Bañón-Rodríguez I, Esteller M, Moreno-Bueno G,
Palacios J. Transcriptional profiling of MCF7 breast cancer cells in response to 5-fluorouracil: Relationship with cell cycle changes and apoptosis, and identification of novel targets of p53. Int J Cancer. 2006; 119: 1164-75.

Li XH, He XR, Zhou YY, Zhao HY, Zheng WX, Jiang ST, Zhou Q, Li PP, Han SY. Taraxacum mongolicum extract induced endoplasmic reticulum stress associated-apoptosis in triplenegative breast cancer cells. J Ethnopharmacol. 2017; 206: 55 -64 .

Liu CY, Hung MH, Wang DS, Chu PY, Su JC, Teng TH, Huang CT, Chao TT, Wang CY, Shiau CW, Tseng LM, Chen KF. Tamoxifen induces apoptosis through cancerous inhibitor of protein phosphatase 2A-dependent phospho-Akt inactivation in estrogen receptor-negative human breast cancer cells. Breast Cancer Res. 2014; 16: 431.

Mosaddegh M, Taheri M, Eslami Tehrani B, HamzelooMoghadam M. Apoptotic potential of two Caryophyllaceae species in MCF-7 and MDA-MB-468 cell lines. Res J Pharmacogn. 2018; 5: 63-69.

Mostafapour Kandelous H, Salimi M, Khori V, Rastkari N, Amanzadeh A, Salimi M. Mitochondrial apoptosis induced by Chamaemelum nobile extract in breast cancer cells. Iran J Pharm Res. 2016; 15(Suppl): 197-204.

National Cancer Institute. https://www.cancer.gov/aboutcancer/treatment/drugs/breast\#2.

Mozaffarian V. A dictionary of plant names. Tehran, Farhange -e-Moaser, 1999, p 13.

Naghibi F, Khalaj A, Mosaddegh M, MalekMohamadi M, Hamzeloo-Moghadam M. Cytotoxic activity evaluation of some medicinal plants, selected from Iranian Traditional Medicine Pharmacopoeia to treat cancer and related disorders. J Ethnopharmacol. 2014; 155: 230-39.

Pardini B, Kumar R, Naccarati A, Novotny J, Prasad RB, Forsti A, Hemminki K, Vodicka P, Bermejo JL. 5-Fluorouracilbased chemotherapy for colorectal cancer and MTHFR/ MTRR genotypes. Br J Clin Pharmacol. 2011; 72: 162-63.

Perry RR, Kang Y, Greaves B. Effects of tamoxifen on growth and apoptosis of estrogen-dependent and -independent human breast cancer cells. Ann Surg Oncol. 1995; 2: 238-45.

Safarzadeh E, Shotorbani SS, Baradaran B. Herbal medicine as inducers of apoptosis in cancer treatment. Adv Pharm Bull. 2014; 4: 421-27.

Tursun K, Rui Z, Hong Z. Study on antioxidant activity of Acroptilon repens. Lett Biotechnol. 2010; 21: 406-12.

Wang F, Wang YH, Wang JJ, Xu HL, Wang CM. Eriodictyolinduced anticancer and apoptotic effects in human hepatocellular carcinoma cells are associated with cell cycle arrest and modulation of apoptosis-related proteins. Bangladesh J Pharmacol. 2016; 11: 285-91.

Zhao P, Fu J, Yao B, Song Y, Yuan L, Jia Y, Ma S, Chen W, Zhou $Z$. The cell cycle distribution should be given more consideration in cell-based in vitro toxicological studies. Arch Toxicol. 2014; 88: 337-43. 